\title{
大学における臨床製剤設計の事例とそのニーズへの対応
}

\author{
米持悦生
}

\section{Examples of Clinical Formulation Design at a University and Response to Clinical Need}

\author{
Etsuo Yonemochi \\ School of Pharmacy and Pharmaceutical Sciences, Hoshi University; 2-4-41 Ebara, \\ Shinagawa-ku, Tokyo 142-8501, Japan.
}

(Received May 3, 2019)

\begin{abstract}
In the healthcare setting, the handling of clinical preparations is essential for the development of tailor-made pharmaceutical agents. However, during the design and development of new clinical formulations, pharmacists may encounter various questions and problems related to handling the formulations, such as a lack of knowledge of and experience in prescription design. In addition, if pharmacists require assistance to solve problems, it is rare to find a person with sufficient knowledge of and experience with the formulation in their facilities, and there are few connections among facilities; therefore, in practice, no consultants are available for advice. Universities may play an important role in solving this problem. We believe that it would be beneficial for both clinical practitioners and universities to develop a plando-check-action (PDCA) cycle that brings needs, problems, and questions from clinical sites to universities where research is conducted and the results are fed back to the clinics. This complements one of the major missions of universities as research institutes, which is to compile evidence. For new drug candidates that require a high degree of support from universities, the demonstration of sufficient safety information to warrant clinical trials and subsequent drug development will increase pharmacists' awareness of drugs and lead to uptake of formulations. This paper introduces the case for clinical formulation design in universities as part of the $\mathrm{C}$ (check) element of the PDCA cycle and how this corresponds to the needs of the pharmaceutical industry.
\end{abstract}

Key words — clinical formulation design; plan-do-check-action cycle; evidence; university mission

\section{1. はじめに}

臨床の現場において，臨床製剤を取り扱うことは 製剤学的テーラーメイド医療を実現するために，必 要不可欠である。しかし新たな臨床製剤の開発を試 みようにも，製剤を扱うことに対するハードルの高 さ，すなわち処方設計のための知識と経験の不足か ら，様々な疑問や問題に遭遇し，それらを臨床現場 の知識のみで解決することが困難なことも少なくな い. また, 関連する問題を解決する糸口を欲して も，一施設に知識や経験を持った製剤担当者がいる ことは稀であり，他施設へのつながりも少ないた め，相談者がいないという現実もある.

本課題をクリアするために,「大学」は重要な役

星薬科大学薬学部（下142-8501 東京都品川区荏原 2-441)

e-mail: e-yonemochi@ hoshi.ac.jp

本総説は, 日本薬学会第 138 年会シンポジウム S52 で 発表した内容を中心に記述したものである.
割を果たせるのではないだろうか. 臨床現場側から のニーズ・問題点・疑問を大学に持ち込夕研究し, 得られた結果を臨床現場にフィードバックできるよ うな plan-do-check-action（PDCA）サイクルを構 築することは, 臨床現場にとっても大学にとっても 有益であると考えられる. 研究機関としての大学の 大きな使命の 1 つは, エビデンスの構築にほかなら ない. 大学が高いニーズを持つた新たな製剤の候補 について, 臨床試験に十分耐え得る安全性の根拠を 示し，臨床製剂開発のサポートをすることは，製剂 に対する意識の高い薬剤師の育成にも結びつき, 臨 床製剤の普及につながるであろう。本稿では, PDCA サイクルの，C（Check）として，大学にお ける臨床製剂設計の事例と, そのニーズへの対応に ついて紹介する.

2. 実例 ウリナスタチン注射液充填中空坐剤の 調製と評価

日本病院薬剤師会平成 26 年度学術委員会学術第 4 

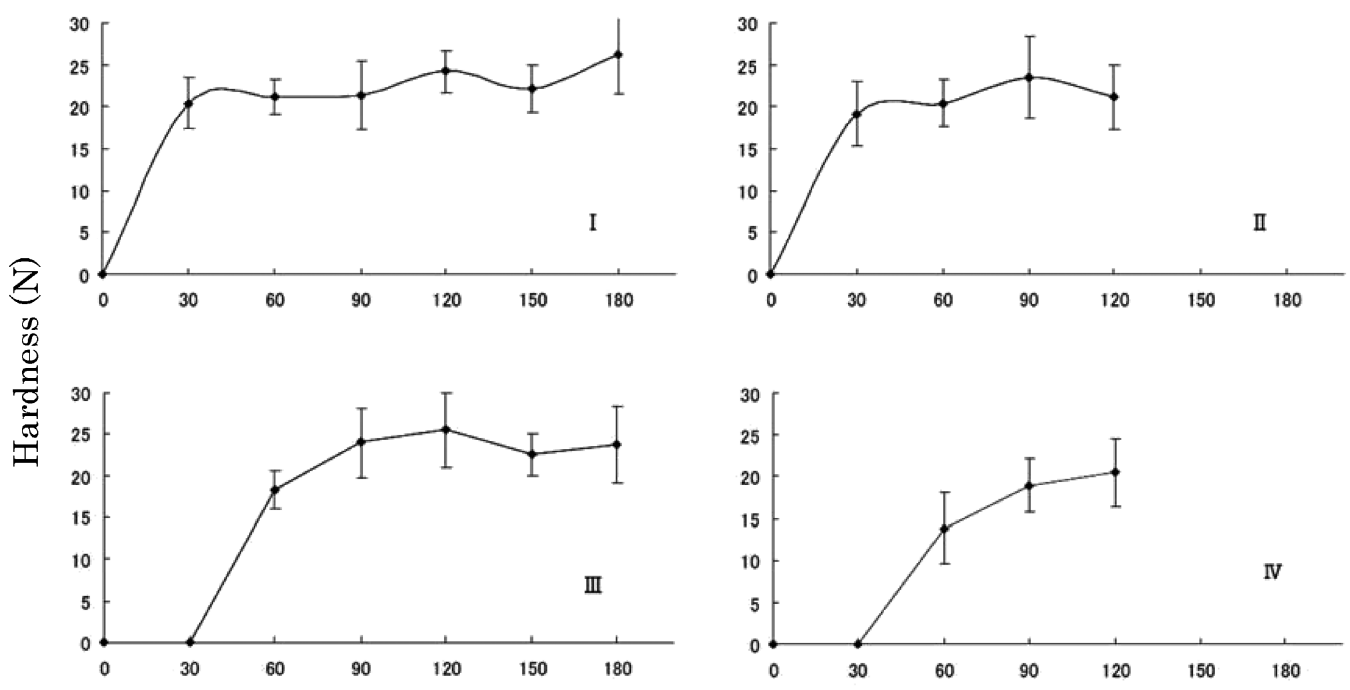

Time (min)

Fig. 1. Change in Hardness of Oily-base Suppository Materials during Storage

I: H-15 $(2.25 \mathrm{~mL}), \mathrm{II}: \mathrm{H}-15(1.35 \mathrm{~mL})$, III: S-55 $(2.25 \mathrm{~mL})$, IV: S-55 $(1.35 \mathrm{~mL})$. The numbers in parentheses are the container volume.

小委員会報告の医療現場に必要な薬剤の市販化に向 けた調査・研究（最終報告）によれば，調査対象 42 施設のうち最も要望の多かった薬剤に，ウリナ スタチン腔坐剤が挙げられていた. ${ }^{1)}$ ウリナスタチ ン腔坐薬は切迫早産の治療に用いられ，多くの病院 では院内製剤として使用されているものの，製剤化 には課題が多かった。具体的には，ウリナスタチン が水溶性タンパクであるため坐剤の脂溶性基剤に均 一な分散が困難であること，また，簡便な定量試験 はトリプシン活性の阻害反応を吸光度試験により測 定することであるが，基剤のハードファットが吸光 度測定の障害であった。 ${ }^{2,3)}$ 中空坐剤の製剤学的な特 性については，これまでに種々の医薬品を用いた多 くの報告があり，主薬の放出が速い，基剤選択の幅

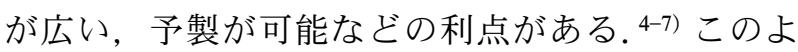
うに中空坐薬は，前述の問題点を克服するには最適 な方法であったが，構造中に空洞を持つため十分な 硬度が得られないなど改善の余地が多く，調製方法 の最適化が必要であった.

中空坐剤の調製は，プラスチック製坐薬コンテナ を用いて以下の手順により行われる． $50^{\circ} \mathrm{C}$ 前後に 加温融解した基剤 [ハードファット $\mathrm{H}-15, \mathrm{~S}-55$ ， ホ スコ ${ }^{\circledR}$ ，丸石製薬(株)，大阪］を坐薬コンテナに注 ぎ，アルミパイプをパイプが正確に垂直及び中央,

深さ $2.5 \mathrm{~cm}$ となるように固定し，放冷固化させ た。放置後，パイプを $40^{\circ} \mathrm{C}$ に加熱し，坐剂に亀裂

が入らないように引き抜いた。次に，ミラクリッド 注射液 $0.1 \mathrm{~mL}$ をマイクロピペットで正確に測りと り，中空部に充填し，溶解した基剂で中空部を塞い だ。本製剤の重要品質特性は，十分な強度と安定性 であるため，強度に関する検討項目は，中空部径， 硬化時間，安定性については，活性のほかに吸湿 性，溶解特性を評価した，基剤の固化時間を検討す るため，中空坐剤の硬度と放置時間の関係を Fig. 1 に示す。各試料とも経時的に硬度上昇を示し，硬度 $20 \mathrm{~N}$ 程度となった後は硬度上昇が緩やかであっ た。試料 I, II の H-15 は, 冷却後すぐに硬度上昇 が始まったが，S-55 III，IV は，30 分程度のラグタ イムが観測された，適切な放置時間は H-15 では 30-60 分, S-55 は 90 分以降が適切であると考えら れた．さらに，固化の開始時間や進行は，コンテナ サイズには無関係であり基剤の種類に固有であるこ とが明らかとなった，坐剂基剂の硬化時における結 晶性の変化を粉末 $\mathrm{X}$ 線回折測定により評価した結 果をFig. 2 に示す。図中の基剤の結晶化を示す

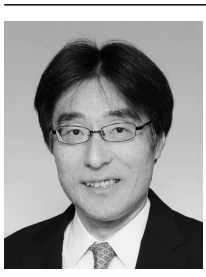

米持悦生
新潟県妙高市出身, 1987 年千葉大学薬 学部 教務職員・助手, 1997 年文部省 在外研究員 ロンドン大学薬学部, 1998 年東邦大学薬学部 助教授, 2013 年よ り星薬科大学 教授, 専門は製剂の物性 評価. 
S-55

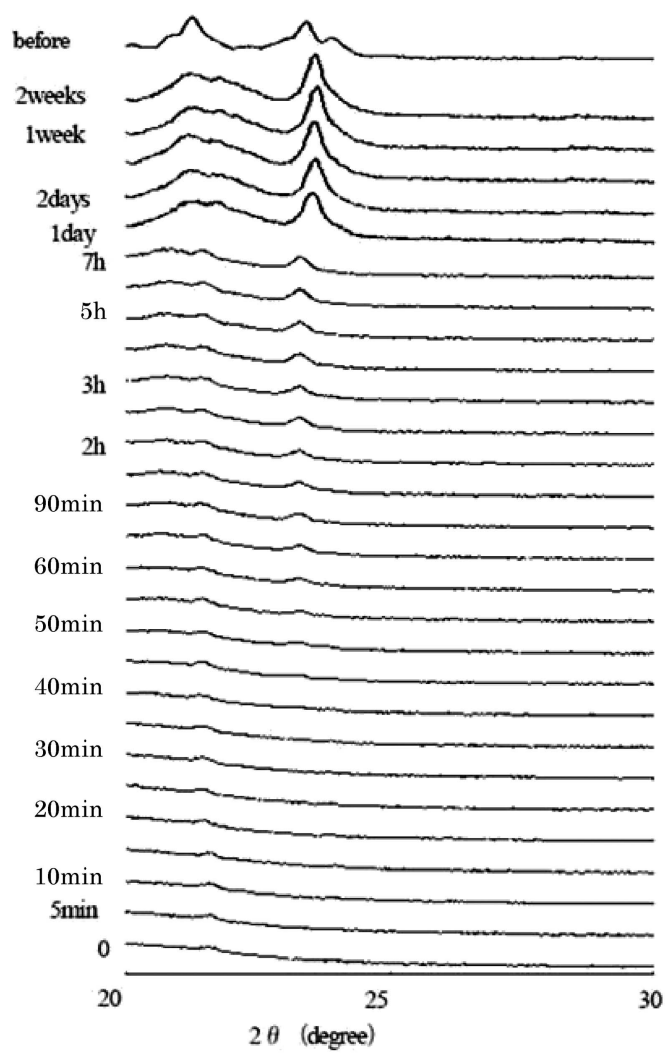

H-15

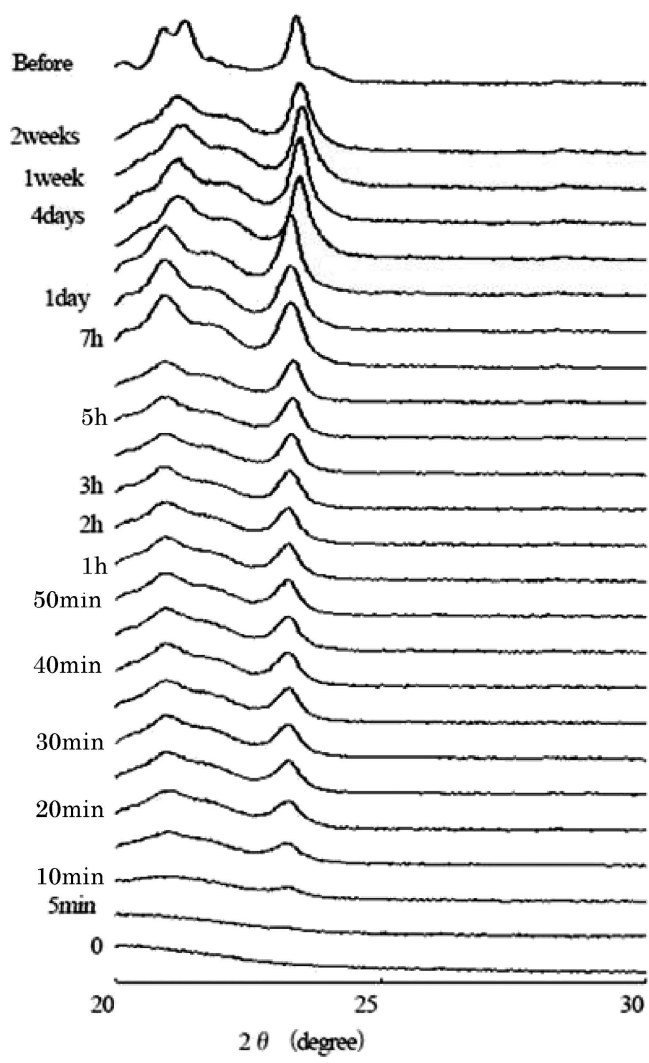

Fig. 2. Change in the X-ray Diffraction Pattern of Oily-base Suppository Materials during Storage

$23.5^{\circ}$ のピークは, H-15 の場合 0 分から確認された が, S-55 では約 40 分以降に出現した。この結果よ り，S-55 よりも H-15 の方が硬度 $20 \mathrm{~N}$ に達するま での時間が早いのは，H15 の方が結晶化の開始及 び進行が早いことよると示唆された. Figure 3 は, 坐剂の硬度と坐剤基剤の結晶化度の経時的な変化を 検討した結果である。図からも明らかなように，両 基剤とも硬度と結晶化度の経時変化は，同様な傾向 を示しており，本製剤の放置時間は結晶化度を指標 にすればよいことが明らかとなつた，次に，放置時 間を固定し中空部の直径が坐剤に及ぼす影響を検討 した結果（Fig. 4)，パイプ直径が大きくなり側壁 の厚さが薄くなるに従い坐剂の硬度が低下した。破 損率は，すべての条件でパイプ直径 $4 \mathrm{~mm}$ までで $10 \%$ 以下であったが，パイプ直径 $5 \mathrm{~mm}, 2.25 \mathrm{~mL}$ の I では，コンテナの破損率は H-15 が 40\%であっ たのに対し，S-55 III では 0\%であった。破損の状 態も，S-55 は亀裂がはいるのに対して H-15 は脆く 崩壊することが多かった．S-55 は H-15 に比べて結 晶化の進行が遅いことが, 破損率や破損状態に影響
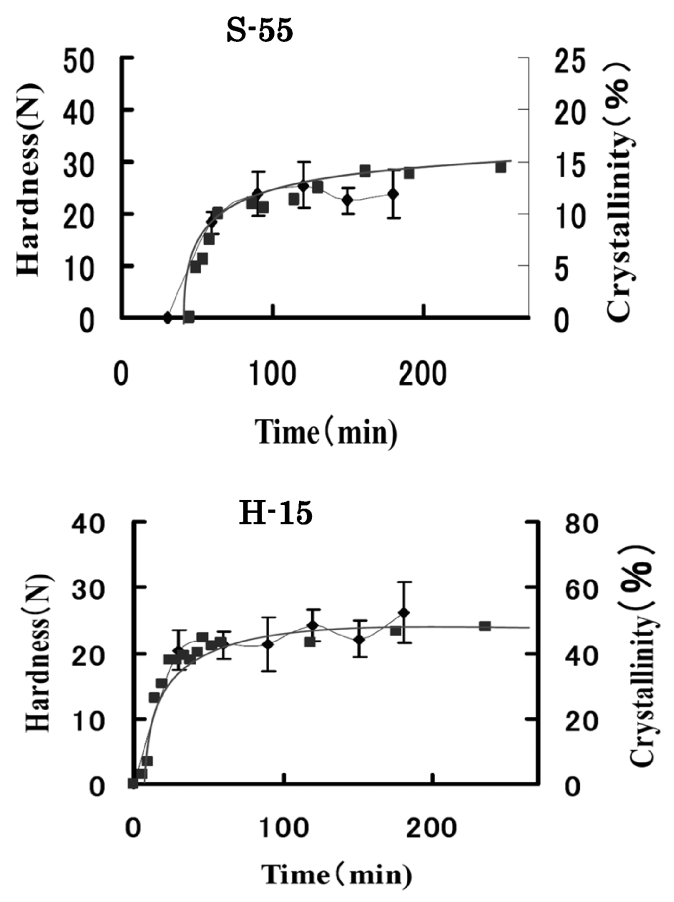

Fig. 3. Relationship between Hardness of Suppository and Crystallinity of Oily-base Suppository Materials 

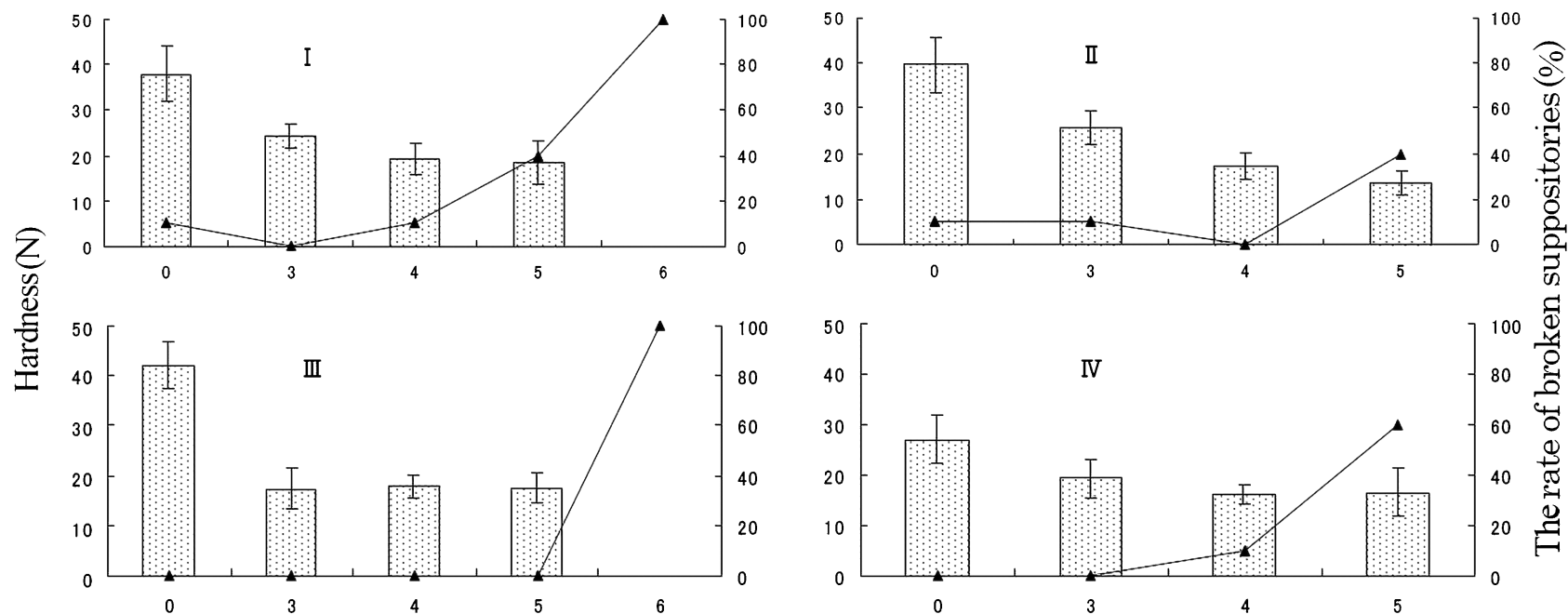

Diameter of the Aluminum Stick (mm)

Hardness $(\mathrm{N})$

The rate of broken suppositories (\%)

Fig. 4. Relationship between Hardness of Suppository and Diameter of the Aluminum Stick

I: H-15 $(2.25 \mathrm{~mL})$, II: H-15 $(1.35 \mathrm{~mL})$, III: S-55 $(2.25 \mathrm{~mL})$, IV: S-55 $(1.35 \mathrm{~mL})$. The numbers in parentheses are the container volume.

しているものと考えられた。これらの結果より，適 切な条件の範囲内で調製することにより，中空坐剤 が安定して製造可能であることが明らかとなつた.

続いて，本製剂を $4^{\circ} \mathrm{C}$ 及び $25^{\circ} \mathrm{C}$ で 4 週間保存し た後の硬度を測定した。その結果 $4^{\circ} \mathrm{C} て ゙$ 保存した S-55 の硬度が $70.8 \mathrm{~N}$ と調製後から 4 週間で約 $20 \mathrm{~N}$ 増加した，一方，H-15 では， $61.0 \mathrm{~N}$ であり，ほと んど変化していなかった．S-55 の硬度上昇は，基 剤の結晶化が徐々に進行したためと考えられた。一 方， $25^{\circ} \mathrm{C}$ で保存した S-55 の硬度は $17.3 \mathrm{~N}, \mathrm{H}-15$ は27.1 N であった。 S-55 の硬度が減少した原因と して基剤が吸湿した可能性が考えられた。硬度測定 中に，作製した坐剤の中空部を確認した結果， $4^{\circ} \mathrm{C}$ で 4 週間保存した S-55 には中空部の薬液が存在し ていたが, $25^{\circ} \mathrm{C}$ で保存した S-55 では薬液が消失し ていた，そこで，H-15，S-55 の吸湿量を測定した 結果を Fig. 5 に示す。 4 週間の保存後，H-15 はほ とんど吸湿しなかったが，S-55 は 0.4\%吸湿してい た。さらに，相対湿度 RH95\%のとき，H-15 の吸 湿量は $0.4 \%$ とあまり増加していなかったが, S-55 の吸湿量は $2.4 \%$ と $\mathrm{H}-15$ の 6 倍の質量増加であり, $\mathrm{S}-55$ の吸湿性が高いことが明らかとなつた。また, $4^{\circ} \mathrm{C}, 28$ 日間保存での主薬安定性は, 含量の低下も なく十分な結果であった。しかし，吸湿性の結果を
考慮し，S-55 を用いた場合，低温で保存し，吸湿 性があるため室温での長期間の保存は避けるべきで あると考えられた。磁気共鳴画像（magnetic resonance imaging; MRI）を用いて，投与時におけ る基剤からの薬物放出挙動を検討した結果を Fig. 6 に示す。 H-15 は $35^{\circ} \mathrm{C}$ において D (15 min) から H (170 min) にかけて基剂部の下部から溶解が進行し 断面積も経時的に減少した。また中空部も断面積が 減少しており，基剤が溶けると同時に中空部の薬が 放出されることが分かった。一方，S-55 の画像で は，I（15 min）から L (170 min) にかけて，基剤 全体の断面積変化は緩やかだった。また，中空部は 断面積が減少し，コントラストが黒色から灰色に変 化していた。この結果は，H-15 の中空坐剂は基剤 の融解と同時に中空部の薬が放出するが，S-55 の 中空坐剂は吸湿性の影響で基剂が融解しなくても薬 が基剤に浸透・分散することが示唆された。このよ うに，基剤の吸湿性により薬の放出挙動が異なるこ とが MRI 測定で確認することができた．以上の検 討結果より，本法はエビデンスに裏付けされ製法と して確立された. ${ }^{8}$

\section{3. エビデンス確立のための分析評価技術}

臨床製剤の品質評価に有用な分析技術には，種々 の分光分析によるイメージング解析が挙げられる. 


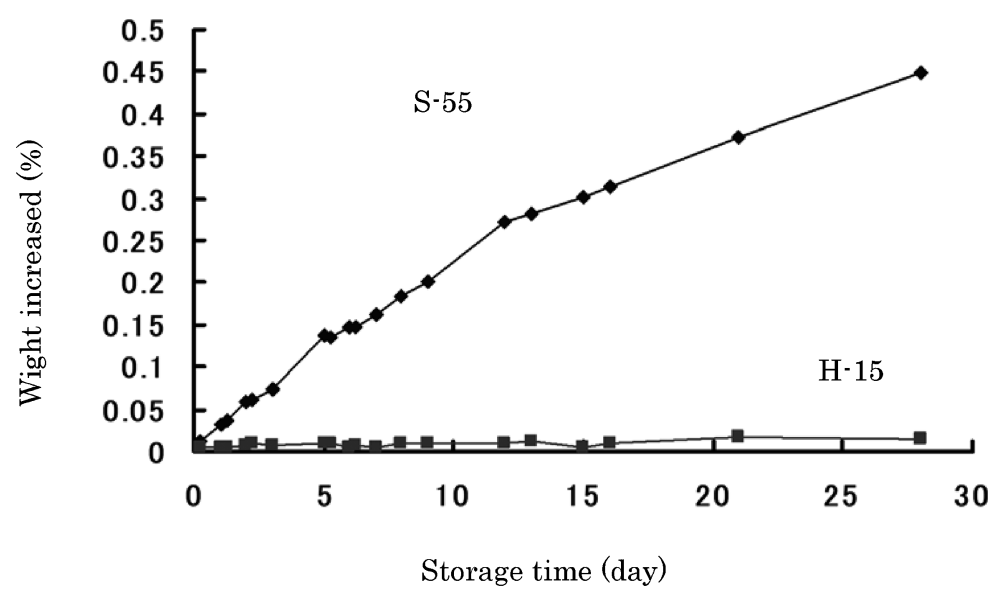

Fig. 5. Change in the Weight of Suppository during Storage at $25^{\circ} \mathrm{C}, \mathrm{RH} 50 \%$

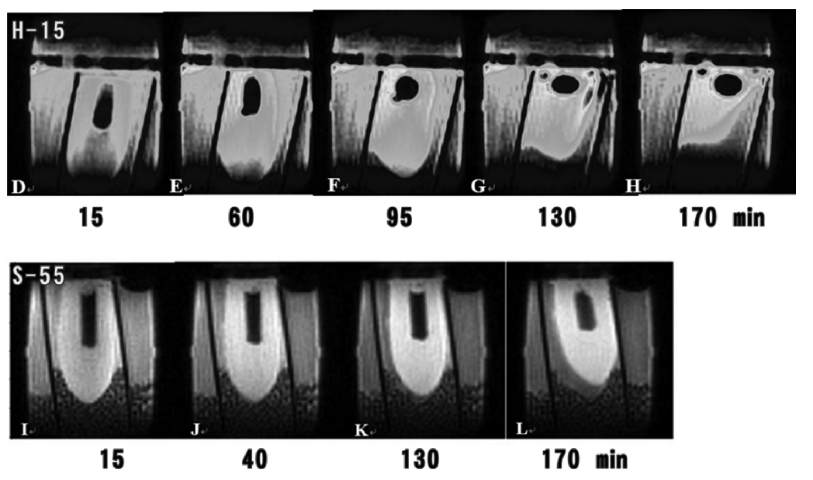

Fig. 6. Change in the MRI Image of Suppository during Storage at $35^{\circ} \mathrm{C}$

山本らは, attenuated total reflection-infrared spectrometry（ATR-IR）イメージング分析により，半 固形製剂の成分の製剂中での分散状態を評価してい る. ${ }^{9)}$ Figure 7 は，アルクロメタゾンプロピオン酸 エステル軟膏中の各成分の分布を示したものであ る. 各図はそれぞれの波数での吸収を基に描かれて おり図中で色が濃い部分は濃度が高い。この製剂の 基剤は白色ワセリンであるが，可溶化剂としてプロ ピレングリコール，ベンジルアルコールが添加され ている. Figure 7 の左からプロピレングリコール $\left(1040 \mathrm{~cm}^{-1}\right)$ ，アルクロメタゾンプロピオン酸エス テル $\left(1656 \mathrm{~cm}^{-1}\right)$, ベンジルアルコール $(1728$ $\left.\mathrm{cm}^{-1}\right)$ それぞれの基剤中での分布を示している. 各可溶化剂と主薬の混合性は, 各図の成分の分布を 重ね合わせて比較することで可能となる，両可溶化 剂を比較すると, 図中矢印で示した部分で, 分布に 違いが認められており，プロピレングリコールの方 がベンジルアルコールよりも主薬との混和性が高い
ことが明らかである。この技術は，臨床製剤で汎用 される半固形製剂中において，各成分の混合均一性 を評価する場合に有用な手段となり得る。ところ で，クリーム（エマルション）製剤は，処方によっ ては高温で保存中に, 水相とエマルション相に分離 することが知られている，大貫らは，Stearic acid， 1-hexadecanol, triisooctanoic acid glyceride を基剤と し，可溶化剂として Polyoxyethylene behenyl ether, Sorbitan monostearate を添加したクリーム製剤の

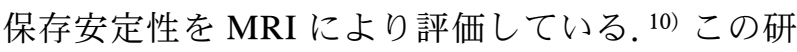
究では，前述のクリーム製剤を高温で保存した場合 のチューブ内での相分離を, MRIにより画像化し たものである. チューブを縦・横に設置し $60^{\circ} \mathrm{C}$ で 2 週間保存した試料について MRI から試料中の見 かけの拡散係数の分布を評価し, 拡散係数の高い領 域（水相）と低い領域（クリーム相）の分離状態を 視覚化した結果を Fig. 8 に示す。図からも明らか なように縦置きしたチューブ内では下部に水相が, 横置きした場合には，水相が上下 2 層に分離してい た.この技術は，チューブに入っている半固形製剤 の保存中における変質を非破壊で測定できるもので あり，外部から中身の見えない製剤の保存安定性な ど臨床製剤の品質評価のエビデンスに有用と考えら れる。

\section{4. おわりに}

臨床製剂に係わる業務には，「調査」，「申請」， 「品質管理」，「モニタリング」が挙げられる。これ ら業務に対して大学が貢献できる点として, 調查に 係わるものには，製剤調製の根拠となる医学的文 献, 品質保証の根拠となる科学的文献の提供が挙げ 

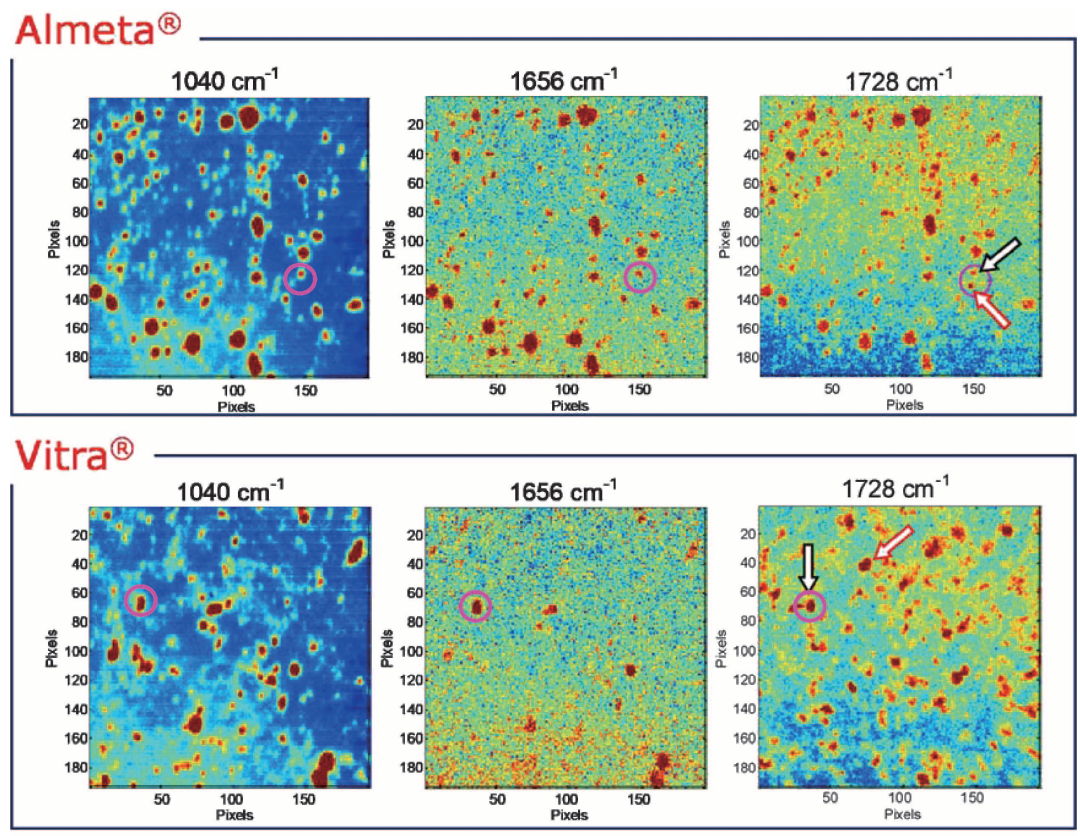

Propylene glycol Alclometasone dipropionate Benzyl alcohol

Fig. 7. ATR-IR Image of Alclometasone Dipropionate Ointments

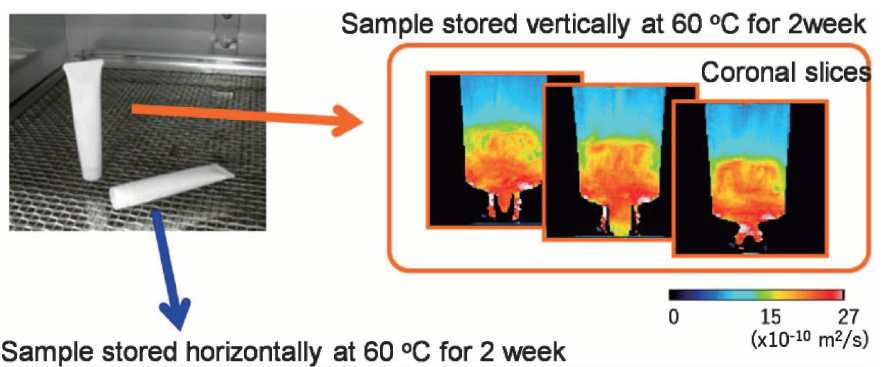

Sample stored horizontally at $60^{\circ} \mathrm{C}$ for 2 week

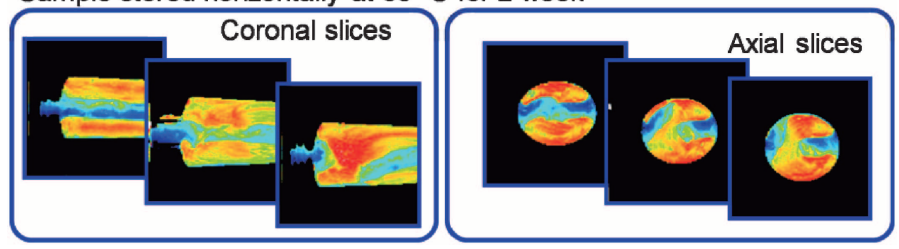

Fig. 8. Change in the MRI Image of Emulsion during Storage at $60^{\circ} \mathrm{C}$

られる，さらに，品質管理については，製剤の調製 方法の最適化, 品質試験の妥当性の検証などが該当 するであろう。現状，一般的な医療機関において， 品質確認を行うために必要な機器等を十分に確保す ることは困難であるが，この問題に対しては，機器 を所有する大学などからの装置の借用や委託等の手 段を講じることで対応可能と考えられる．また，教 育機関としての大学の機能を考えた場合, 臨床現場 の製剂担当者を始めとした多くの薬剤師に，薬剤師 卒後教育の一環として, 臨床製剤に関する新たな情 報の提供，具体的には製剤化技術に関する研修会の
開催が適当と考えられる。ささに，煩雑な申請に関 するサポートとしては, 院内での臨床製剤使用の申 請書類作成方法や品質管理方法についての研修会の 開催も有用と考えられる。大学は，PDCA サイク ルの, C (Check) として, 臨床製剂の物理化学的 性質のエビデンス提供, 臨床応用を実現するための 安全性の根拠の提示，臨床現場における製剂的問 題, 課題解決など現場のニーズに合わせた研究とそ の結果のフィードバックを行う役割を担うべきであ ろう。また，臨床製剤に対する意識の高い薬剤師の 育成のため, 認証制度構築など, 臨床製剤への取り 
組みの更なる活性化が望まれる.

利益相反＼cjkstart開示すべき利益相反はない.

\section{REFERENCES}

1) 4th Subcommittee of the Japan Pharmaceutical Association, J. Jpn. Soc. Hosp. Pharm., 51, 1057-1059 (2015).

2) Kamimura M., Ueta A., Kurita H., Owada K., Ishikawa M., Watanabe M., Fujiwara A., Yamamoto M., Kashiwagi M., Miwa N., Minami S., Iwasaki T., Nabeta I., Kuromi M., Ukishima Y., Misaki Y., Jpn. J. Pharm. Health Care Sci., 33, 775-780 (2007).

3) Osaka M., Minabe A., Asari H., Matsumoto Y., Watanabe Y., Matsumoto M., J. Clinical Anesthesia (Japan), 15, 1037-1040 (1991).

4) Watanabe Y., Katsuyama Y., Ohta S., Zenda H., Matsumoto M., Drug Delivery System, 14,
51-57 (1999).

5) Matsumoto Y., Nakao T., Yuasa H., Akai K., Watanabe Y., Suzuki Y., Matsumoto M., Diagnosis and Treatment, 7, 1717-1722 (1991).

6) Watanabe Y., Matsumoto M., Yakugaku Zasshi, 104, 479-484 (1984).

7) Watanabe Y., Matsumoto Y., Matsumoto M., Yakkyoku, 40, 1599-1602 (1989).

8) Yamaki T., Kaga A., Iwasa S., Yoshihashi Y., Yonemochi E., Masaka T., Terada K., Moriyama H., Abstracts of papers, the 26th Annual Meeting of the Academy of Pharmaceutical Science and Technology, Japan, Tokushima, May 2011, p. 133.

9) Yamamoto Y., Fukami T., Koide T., Suzuki T., Hiyama Y., Tomono K., Int. J. Pharm., 426, 54-60 (2012).

10) Onuki Y., Horita A., Kuribayashi H., Okuno Y., Obata Y., Takayama, K., Drug Dev. Ind. Pharm., 40, 937-943 (2014). 